\title{
Metformin counteracts the effects of FSH on rat Sertoli cell proliferation
}

\author{
Gustavo Marcelo Rindone, Agostina Gorga, Mariana Regueira, Eliana Herminia Pellizzari, \\ Selva Beatriz Cigorraga, María Noel Galardo, Silvina Beatriz Meroni and María Fernanda Riera \\ División de Endocrinología, Centro de Investigaciones Endocrinológicas 'Dr. César Bergadá' (CEDIE), CONICET, FEI, \\ Hospital de Niños Ricardo Gutiérrez, Buenos Aires, Argentina \\ Correspondence should be addressed to M F Riera; Email: friera@cedie.org.ar
}

\begin{abstract}
Metformin (MET) is one of the most widely used anti-hyperglycemic agents for treating patients with type 2 diabetes and it has started to be used in pediatric population at ages when Sertoli cells are still proliferating. It is well known that follicle-stimulating hormone (FSH) is the major Sertoli cell mitogen. The aim of the study is to investigate a possible effect of MET, which has been shown to have anti-proliferative properties, on FSH regulation of postnatal Sertoli cell proliferation and on the molecular mechanisms involved in this regulation. The present study was performed in eight-day-old rat Sertoli cell cultures. The results obtained show that MET in the presence of FSH increases phosphorylated acetyl-CoA carboxylase and decreases phosphorylated p70S6K levels. Moreover, we show that MET decreases FSH-stimulated Sertoli cell proliferation, and this decrease is accompanied by a reduction in FSH-stimulated Ccnd1 and Ccnd2 expression and an increase in cell cycle inhibitor p21 ${ }^{\text {Cip }}$ expression. Altogether, these results suggest that MET can, at least in part, counteract the effect of FSH on postnatal Sertoli cell proliferation.

Reproduction (2018) 156 93-101
\end{abstract}

\section{Introduction}

Sertoli cell proliferation occurs during a restricted period of time. In rats, Sertoli cells proliferate throughout fetal life and up to 15 days of postnatal age. At around 15-18 days of age, the blood-testis barrier is formed, and Sertoli cells keep on differentiating to be able to support full spermatogenesis. In humans, Sertoli cells proliferate during fetal and neonatal periods up to 6 months after birth and at the onset of puberty (Sharpe et al. 2003, Rey et al. 2016). The final number of Sertoli cells reached during the proliferative periods determines sperm production capacity in adulthood, therefore, is of paramount importance to evaluate possible external factors that may alter Sertoli cell proliferation.

Metformin (MET) is one of the most widely used antihyperglycemic agents for treating patients with type 2 diabetes (T2D). In addition to its strong antidiabetic properties, numerous studies have demonstrated the anti-proliferative activity of MET in cancer cells. It has been shown that it inhibits proliferation of glioma, breast, ovary and prostate cancer cells among others (Isakovic et al. 2007, Ben Sahra et al. 2008, Rattan et al. 2011). Despite the latter findings, few studies have analyzed the effect of this drug in non-cancer cells. Particularly in the testis, Tartarin et al. (2012) have shown that in vivo administration of MET to pregnant mice reduces the number of Sertoli cells in the male fetus. However, it has not been determined yet if MET has any effect on the hormonal regulation of postnatal Sertoli cell proliferation and if so, the potential mechanisms that may be participating.

Several studies have shown that MET exerts its anti-proliferative action partly by activating AMPactivated protein kinase (AMPK) (Zakikhani et al. 2006, 2008). AMPK is a serine/threonine protein kinase that maintains cellular energy homeostasis, which once activated turns on catabolic pathways that generate ATP and turns off pathways that consume ATP (Gowans \& Hardie 2014). AMPK is activated in response to ATP depletion leading to an increase in the intracellular AMP:ATP ratio. It is activated allosterically by AMP and by phosphorylation by upstream kinases (Hardie et al. 2006). Acetyl-CoA carboxylase (ACC) is one of the best characterized downstream targets of AMPK. Even though it was observed that MET activates AMPK in chicken Sertoli cells (Faure et al. 2016), the capacity of the drug to activate AMPK in mammalian testis has not been analyzed yet.

Follicle-stimulating hormone $(\mathrm{FSH})$ regulates Sertoli cell proliferation and differentiation after cessation of mitosis. MAPK, PI3K/Akt and mTORC1/p70SK6 pathways have been involved in FSH-stimulated Sertoli cell proliferation (Crépieux et al. 2001, Riera et al. 2012). We have previously observed that pharmacological activation of AMPK by AICAR and A769662, specific 
AMPK activators, leads to a decrease in the activity of mTORC1/p70S6K pathway and in FSH-stimulated Sertoli cell proliferation (Riera et al. 2012). As mentioned before, the anti-proliferative effect of MET observed in different cell types is exerted through the activation of AMPK. Thus, we hypothesized that MET might be counteracting the action of FSH on Sertoli cell proliferation.

Proliferation of human immature Sertoli cells occurs at the onset of puberty when the increase in FSH levels induces mitosis of this cell type. This increase in Sertoli cell number leads to a duplication of testicular volume from 2 to $4 \mathrm{~mL}$, clinically reflected in Tanner stage 2 (Rey et al. 2016). At this point, it is important to remind that the incidence of both T2D and obesity in children has risen at staggering rates and that MET has started to be used in pediatric population at the time when Sertoli cells are proliferating (Brufani et al. 2013, Adeyemo et al. 2015, Smith et al. 2016). If MET alters postnatal Sertoli cell proliferation in mammalian testis, it should be considered a warning about possible deleterious effects on future fertility when this drug is used in children. The aim of the present study is to investigate a possible effect of MET on FSH regulation of postnatal rat Sertoli cell proliferation and of the possible molecular mechanisms involved, as a first approach to the issue.

\section{Materials and methods \\ Materials}

MET was purchased from Sigma-Aldrich. Ovine FSH (NIHoFSH-S-16) was obtained from the National Hormone and Pituitary Program, NIDDK, Bethesda, MD, USA. Tissue culture media and all other drugs were purchased from Sigma-Aldrich.

\section{Sertoli cell isolation and culture}

Sertoli cells from eight-day-old Sprague-Dawley rats were isolated as previously described (Riera et al. 2012). Animals were housed and used according to the guidelines recommended by the National Institute of Health and approved by the Institutional Ethical Committee. Animals were killed by cervical dislocation. Briefly, testes were removed, decapsulated and incubated in culture medium containing $0.03 \% \mathrm{w} / \mathrm{v}$ collagenase and $0.003 \% \mathrm{w} / \mathrm{v}$ soybean trypsin inhibitor, for $5 \mathrm{~min}$ at room temperature. Culture medium consisted of a 1:1 mixture of Ham's F-12 and Dulbecco's modified Eagle's medium, supplemented with $0.1 \% \mathrm{w} / \mathrm{v}$ BSA, $100 \mathrm{IU} / \mathrm{mL}$ penicillin, $2.5 \mu \mathrm{g} / \mathrm{mL}$ amphotericin $\mathrm{B}$ and $1.2 \mathrm{mg} / \mathrm{mL}$ sodium bicarbonate. After the initial dispersion, seminiferous tubules were sedimented and supernatant was discarded to remove interstitial cells. Seminiferous tubules were treated with $1 \mathrm{M}$ glycine-2 mM EDTA $(\mathrm{pH} 7.4)$ to remove peritubular cells. Tubules washed with culture media and recovered by sedimentation were treated with collagenase for a second time. Tubules were incubated for $10 \mathrm{~min}$ at room temperature with a solution of $0.03 \% \mathrm{w} / \mathrm{v}$ collagenase and $0.003 \% \mathrm{w} / \mathrm{v}$ soybean trypsin inhibitor and $0.03 \% \mathrm{w} / \mathrm{v}$ DNase. The resultant Sertoli cell suspension, collected by sedimentation, was resuspended in the culture medium described earlier without BSA and with the following additions: $10 \mu \mathrm{g} / \mathrm{mL}$ transferrin, $5 \mu \mathrm{g} / \mathrm{mL}$ insulin, $5 \mu \mathrm{g} / \mathrm{mL}$ vitamin $\mathrm{E}$ and $4 \mathrm{ng} / \mathrm{mL}$ hydrocortisone. Sertoli cells were cultured in 6- or 24-multiwell plates and in 8-chamber Permanox slides $\left(5 \mu \mathrm{g} \mathrm{DNA} / \mathrm{cm}^{2}\right)$ at $34^{\circ} \mathrm{C}$ in a mixture of $5 \%$ $\mathrm{CO}_{2}: 95 \%$ air.

\section{Culture conditions}

Sertoli cells were allowed to attach for $48 \mathrm{~h}$ in culture medium mentioned earlier. A medium change was performed at this time (day 3) with fresh medium without insulin. As indicated in figure legends, treatments with different doses of MET in the absence or presence of $100 \mathrm{ng} / \mathrm{mL}$ of FSH were started on day 3. This concentration of FSH has been previously shown to elicit maximal biological response (Meroni et al. 2002). Cells harvested on day 4 were used to evaluate BrdU incorporation, to count cell number or to perform RT-qPCR analysis. For Western blot analysis, cells maintained under Basal conditions until day 4 and treated as indicated in figure legends were used.

\section{Cell extracts and Western blot analysis}

Sertoli cells cultured in six multiwell plates were washed once with PBS at room temperature. Then, $200 \mu \mathrm{L}$ PBS containing $2 \mu \mathrm{L}$ protease inhibitor cocktail Sigma-Aldrich (P-8340), $1 \mathrm{mM}$ $\mathrm{NaF}, 1 \mathrm{mM}$ EGTA, $1 \mathrm{mM}$ EDTA, $50 \mathrm{nM}$ okadaic acid and $2 \mathrm{mM}$ PMSF were added to each well and cells were disrupted by ultrasonic irradiation. A $200 \mu \mathrm{L}$ volume of $2 \times$ Laemmli buffer was added and thoroughly mixed. Proteins were resolved in $5 \%$ or $10 \%$ SDS-PAGE in a Mini Protean 3 Cell (Bio-Rad). After SDS-PAGE, gels were equilibrated in transfer buffer for $10 \mathrm{~min}$ and electrotransferred at $100 \mathrm{~V}$ for $60 \mathrm{~min}$ onto PVDF membranes (Hybond-P; Amersham Pharmacia Biotech, Little Chalfont, Bucks, UK) using a Mini Trans-Blot Cell (Bio-Rad). Membranes were probed with commercial antibodies that recognize the phosphorylated forms of p70S6K (Thr389) and ACC (Ser79), with antibodies against the non-phosphorylated form of these proteins (Cell Signaling Technology) and with antibodies against Cyclin D1 (Abcam), Cyclin D3 and AKT (Cell Signaling Technology). 1:1000 dilutions of primary antibodies were used. The intensities of the autoradiographic bands were estimated by densitometric scanning using $\mathrm{NIH}$ Image (Scion Corporation, Frederick, MD, USA) software.

\section{BrdU incorporation}

Sertoli cell monolayers cultured in eight-chamber Permanox slides were incubated with $\operatorname{BrdU}(10 \mu \mathrm{M})$ for the last $24 \mathrm{~h}$ of culture. Subsequently, cells were washed with PBS and fixed with methanol:acetic acid (3:1) for 30min for immunocytochemistry. DNA was denatured with $70 \%$ ethanol and $0.2 \mathrm{M} \mathrm{NaOH}$ for $3 \mathrm{~min}$ followed by cold $70 \% \mathrm{v} / \mathrm{v}$ and absolute ethanol (1 min each), allowing the plate to dry. Endogenous peroxidase and nonspecific sites were blocked with $\mathrm{H}_{2} \mathrm{O}_{2}$ in $3 \%$ methanol and horse serum in PBS for $30 \mathrm{~min}$, respectively. Finally, cells were incubated with monoclonal BrdU antibody (1/200; Dako) in wet chamber at $4^{\circ} \mathrm{C}$ overnight. 
Immunoperoxidase staining was performed according to the manufacturer's recommended protocol for universal-labeled streptavidin biotin/system horseradish peroxidase (Vectastain Elite ABC HRP Kit; Vector Laboratories, Burlingame, CA, USA). Nuclei were counterstained with hematoxylin, and over 2000 cells were counted. The percentage of proliferating (BrdUpositive) Sertoli cells was calculated as (BrdU-positive cells/ total Sertoli cells) $\times 100$.

\section{Cell count assay}

Sertoli cell monolayers cultured in 24-multiwell plates were washed twice with PBS and then cells were recovered by trypsinization. Cell suspension was centrifuged for $5 \mathrm{~min}$ at $400 \mathrm{~g}$ and the cell pellet was recovered. Cells were resuspended in fresh medium and $0.4 \% \mathrm{w} / \mathrm{v}$ trypan blue was added. Cells that excluded the colorant - viable - and those that resulted stained - non-viable - were counted in a Neubauer chamber. Results are express as means \pm S.D. of triplicate incubations.

\section{Real-time PCR (RT-qPCR)}

Total RNA was isolated from Sertoli cells cultured in six multiwell plates with TRI reagent (Sigma-Aldrich) according to the manufacturer's recommendations. The amount of RNA was estimated by spectrophotometry at $260 \mathrm{~nm}$. Reverse transcription was performed as previously described (Riera et al. 2012). Real-time PCR was performed using Step One Real-Time PCR System (Applied Biosystems). Table 1 shows the specific primers used to analyze Ccnd1-d3, Ccne1-e2, $p 21^{\text {Cip }}, p 27^{\text {Kip }}, c-M y c, A c t b$ and B $2 m$ expression. Amplification was carried out as recommended by the manufacturer: $25 \mu \mathrm{L}$ reaction mixture contained $12.5 \mu \mathrm{L}$ of SYBR Green PCR Master mix (Applied Biosystems), the appropriate primer concentration and $1 \mu \mathrm{L}$ of cDNA. The relative cDNA concentrations were established by a standard curve using sequential dilutions of a cDNA sample. The data were normalized to Actb and $B 2 m$.
The amplification program included the initial denaturation step at $95^{\circ} \mathrm{C}$ for $10 \mathrm{~min}, 40$ cycles of denaturation at $95^{\circ} \mathrm{C}$ for $15 \mathrm{~s}$ and annealing and extension at $60^{\circ} \mathrm{C}$ for $1 \mathrm{~min}$. Fluorescence was measured at the end of each extension step. After amplification, melting curves were acquired and used to determine the specificity of PCR products. The comparative $\Delta \Delta \mathrm{Ct}$ method was used to calculate the relative gene expression.

\section{Statistical analysis}

All experiments were run in triplicate and repeated four times. Results were expressed as mean \pm S.D. One-way ANOVA followed by Tukey-Kramer test using GraphPad InStat, version 3.01 (GraphPad Software) was performed. Probabilities $<0.05$ were considered statistically significant.

\section{Results}

\section{Effect of MET on P-ACC and P-p70S6K levels in Sertoli cells}

As mentioned in the introduction, MET activates AMPK in different cell types. To check whether this activation also occurs in mammalian testis, rat Sertoli cell cultures were incubated for variable periods of time $(2,4,6$ and $24 \mathrm{~h}$ ) with $10 \mathrm{mM}$ MET or for $24 \mathrm{~h}$ with variable doses of MET (0.5, 1 and $10 \mathrm{mM})$. Phosphorylated ACC (P-ACC) levels, which reflect AMPK activation, were evaluated. Figure $1 \mathrm{~A}$ (left) shows that $10 \mathrm{mM}$ MET produced a timedependent increase in P-ACC levels that is statistically significant in 4-, 6- and 24-h incubation periods. Figure $1 \mathrm{~A}$ (right) shows that all doses tested of MET increase P-ACC levels. Given our previous observation that the activation of AMPK in Sertoli cells led to a decrease in the activity of mTORC1/p70S6K pathway (Riera et al. 2012), we further evaluated the effect of MET

Table 1 Rat-specific primers sets for analysis by RT-qPCR.

\begin{tabular}{|c|c|c|c|}
\hline Gene & Accession number & Primer sequence & Product length $(b p)$ \\
\hline Cyclin D1 (Ccnd1) & NM_171992.4 & $\begin{array}{l}\text { 5'-CTACCGCACAACGCACTTTC-3' } \\
\text { 5'-AAGGGCTTCAATCTGTTCCTG-3' }\end{array}$ & 85 \\
\hline Cyclin D2 (Ccnd2) & NM_022267.1 & $\begin{array}{l}\text { 5'-CTGACCAAGATCACCCACAC-3' } \\
\text { 5'-CTCTTAGACGGAACTGCTGAAG-3' }\end{array}$ & 99 \\
\hline Cyclin D3 (Ccnd3) & NM_012766.1 & $\begin{array}{l}\text { 5'-GAAACCACACCCCTGACTATTG-3' } \\
\text { 5'-AGGTCCСАСTTGAGCTTCC-3' }\end{array}$ & 113 \\
\hline Cyclin E1 (Ccne1) & NM_001100821.1 & $\begin{array}{l}\text { 5'-ACAGCTTATTGGGATTTCAGC-3' } \\
\text { 5'-GGAGCAAGCACCATCAGTAAC-3' }\end{array}$ & 103 \\
\hline Cyclin E2 (Ccne2) & NM_001108656.1 & $\begin{array}{l}\text { 5'-AGCCAGACTCTCCACAAGAAG-3' } \\
\text { 5'-ATTCCTCCAGACAGTACAGGTG-3' }\end{array}$ & 145 \\
\hline p21 Cip (Cdkn1a) & NM_080782.3 & $\begin{array}{l}\text { 5'-GTCTTGCACTCTGGTGTCTCA-3' } \\
\text { 5'-GCACTTCAGGGCTTTCTCTT-3' }\end{array}$ & 156 \\
\hline$p 27^{K i p}(C d k n 1 b)$ & NM_031762.3 & $\begin{array}{l}\text { 5'-TTCGACGCCAGACGTAAAC-3' } \\
\text { 5'-TTCAATGGAGTCAGCGATATG-3' }\end{array}$ & 126 \\
\hline MYC proto-oncogene $(c-M y c)$ & NM_012603.2 & $\begin{array}{l}\text { 5'-CACCAGCAGCGACTCTGAA-3' } \\
\text { 5'-GACCСTGACTCGGACCTCTT-3' }\end{array}$ & 102 \\
\hline$\beta$-actin $(A c t b)$ & NM_031144.3 & $\begin{array}{l}\text { 5'-TGGCACCACACTTTCTACAAT-3' } \\
\text { 5'-GGTACGACCAGAGGCATACA-3' }\end{array}$ & 189 \\
\hline Beta-2 microglobulin $(B 2 m)$ & NM_012512.2 & $\begin{array}{l}\text { 5'-CGTGATCTTTCTGGTGCTTG-3' } \\
\text { 5'-GAGGTGGGTGGAACTGAGAC-3' }\end{array}$ & 143 \\
\hline
\end{tabular}


A
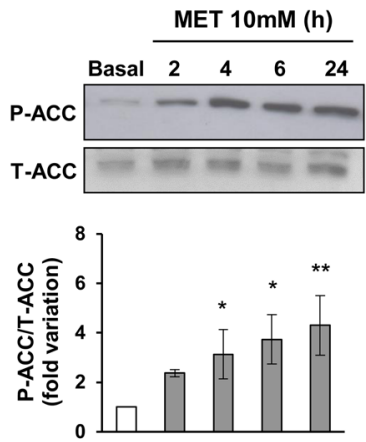

B
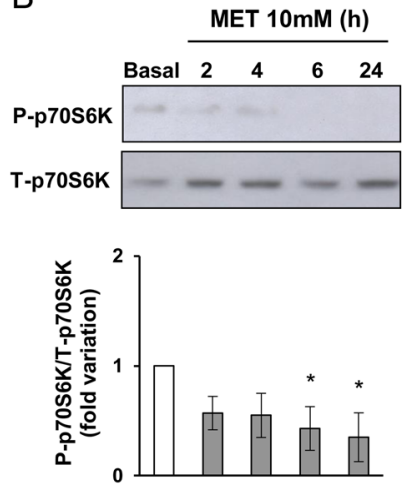
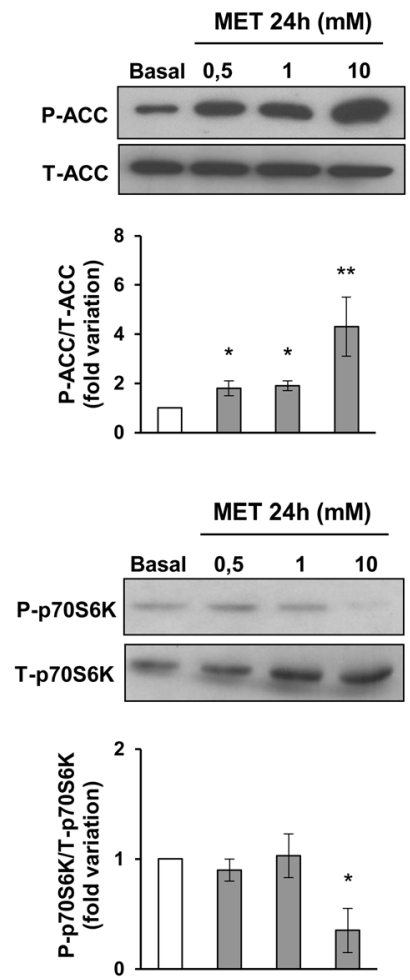

Figure 1 Effect of metformin on P-ACC and P-p70S6K levels in Sertoli cells. Sertoli cell monolayers were maintained under Basal conditions or incubated for variable periods of time with $10 \mathrm{mM}$ metformin (MET; A and B left panel). Additionally, Sertoli cells were incubated with variable doses of metformin for $24 \mathrm{~h}$ ( $\mathrm{A}$ and $\mathrm{B}$ right panel). Western blot analysis was performed utilizing antibodies for P-ACC, T-ACC, P-p70S6K and T-p70S6K. The upper panels show a representative experiment out of three. The lower panels show pooled data of three independent experiments indicating the fold variation in phosphorylation (ratio of P-ACC to T-ACC and of P-p70S6K to T-p70S6K in each sample) relative to Basal. Results are expressed as means \pm S.D. ${ }^{*} P<0.05 ;{ }^{*} P<0.01$ vs Basal. A full colour version of this figure is available at https://doi.org/10.1530/ REP-18-0233.

on phosphorylated p70S6K (P-p70S6K) levels. Figure 1B (left) shows that $10 \mathrm{mM}$ MET produced a time-dependent reduction in P-p70S6K levels. Figure 1B (right) shows that the decrease in P-p70S6K levels in 24-h incubation period was only observed with a $10 \mathrm{mM}$ dose of MET.

\section{Effect of MET on Sertoli cell proliferation}

The effect of MET on Sertoli cell proliferation was next evaluated. Sertoli cell cultures were incubated for $24 \mathrm{~h}$ with MET 0.5 or $10 \mathrm{mM}$. Sertoli cell proliferation was assessed by BrdU incorporation into DNA and by counting cells in a Neubauer chamber. Figure 2 shows that $10 \mathrm{mM}$ MET significantly diminished BrdU incorporation into DNA. Cell counting in a Neubauer chamber showed that $10 \mathrm{mM}$ MET decreased the number of Sertoli cells (Basal: $1250 \pm 72$; MET $0.5 \mathrm{mM}$ : $1220 \pm 96$; MET $10 \mathrm{mM}$ : $890 \pm 98^{*}$ number of cells $\times 10^{-2} /$ well; means \pm S.D., $n=3$

Basal

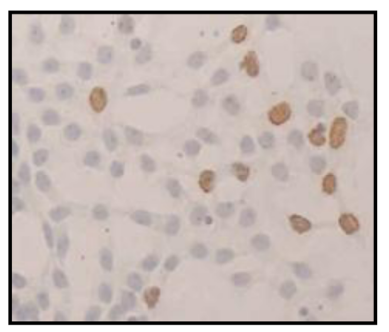

MET $10 \mathrm{mM}$
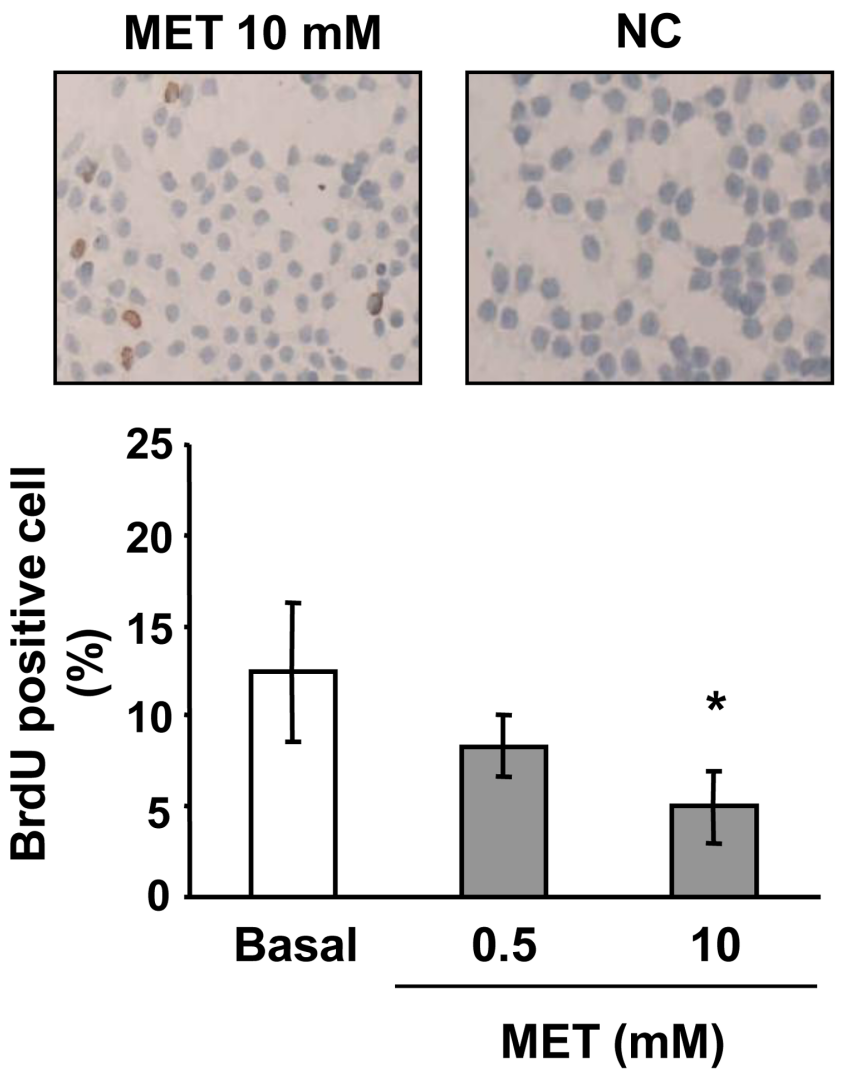

Figure 2 Effect of metformin on Sertoli cell proliferation. Sertoli cell monolayers were maintained under Basal conditions or incubated for $24 \mathrm{~h}$ with metformin $(0.5$ or $10 \mathrm{mM})$. At the end of the culture period, bromodeoxyuridine (BrdU) incorporation was evaluated by

immunocytochemistry. Representative images of Sertoli cells showing immunoreactivity for BrdU (brown) were shown. In the graphic, each bar represents \% BrdU-positive cells (2000 cells/group). Results are presented as means \pm S.D. of four independent experiments. ${ }^{*} P<0.05$ vs Basal. NC, negative control.

${ }^{*} P<0.05$ vs Basal), while it did not affect cell viability, as evaluated by a trypan blue exclusion test (Basal: $15 \pm 5$; MET $0.5 \mathrm{mM}$ : $17 \pm 7$; MET $10 \mathrm{mM}: 16 \pm 8$, number of trypan blue stained cells $\times 10^{-2} /$ well; means \pm S.D., $n=3$ ).

Having demonstrated that MET decreased cell proliferation, we next analyzed if MET regulated the expression of cyclins and cell cycle inhibitors. Figure $3 \mathrm{~A}$ shows that $10 \mathrm{mM}$ MET significantly decreased Ccnd1 and Ccne 1 mRNA levels. Also, this figure shows that MET did not modify the expression 

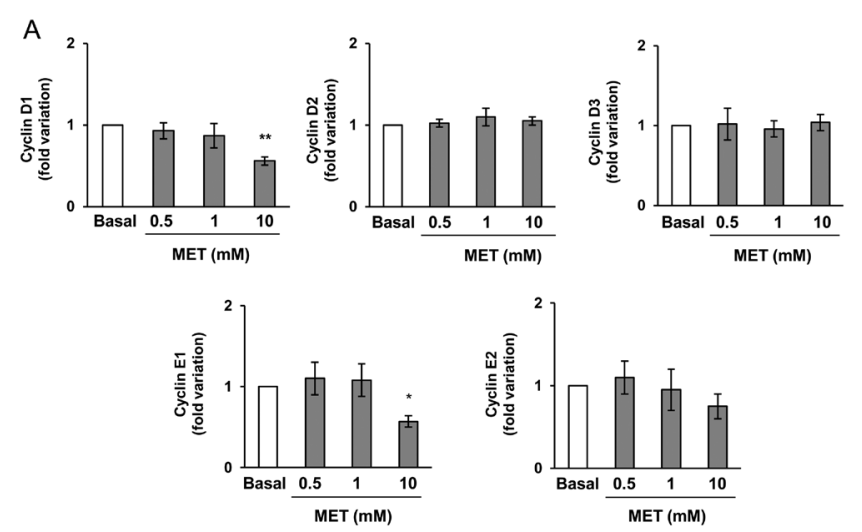

B
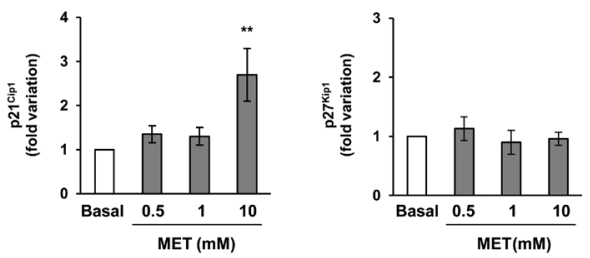

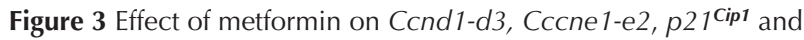
$p 27^{\text {Kip } 1}$ mRNA levels. Sertoli cells were maintained under basal conditions or incubated with variable doses of metformin $(0.5,1$ or $10 \mathrm{mM}$ ) for $6 \mathrm{~h}$ (panel A) or $24 \mathrm{~h}$ (panel B). Then total RNA was extracted and RT-qPCR was performed. Graphics show pooled data from four independent experiments performed indicating fold variation in mRNA levels relative to Basal. Results are expressed as means \pm S.D. ${ }^{*} P<0.05 ;{ }^{* *} P<0.01$ vs Basal.

of $C$ nd2, Ccnd 3 and C cne 3 at any of the doses tested. On the other hand, Fig. 3B shows that $10 \mathrm{mM}$ MET significantly increased $p 21^{\text {Cip } 1}$ mRNA levels, and it did not modify the expression of $p 27^{\text {Kip } 1}$ at any of the doses studied.

\section{Effect of MET on FSH action}

The next set of experiments was designed to analyze whether MET is also able to modulate AMPK and
mTORC1/p70S6K pathways in the presence of FSH, the main Sertoli cell mitogen. To this end, Sertoli cell cultures were maintained under Basal conditions or stimulated for $6 \mathrm{~h}$ with $\mathrm{FSH}(100 \mathrm{ng} / \mathrm{mL})$ in the absence or presence of MET $(10 \mathrm{mM})$. Figure 4 shows that FSH did not decrease the ability of MET to increase P-ACC levels. Also, this figure shows that FSH-stimulated P-p70S6K levels and that the combination with MET significantly decreased the stimulation produced by $\mathrm{FSH}$.

We next explored the potential effects of MET on FSH-stimulated Sertoli cell proliferation. Figure 5 shows that 0.5 and $10 \mathrm{mM}$ MET decreased FSH-stimulated BrdU incorporation into DNA in Sertoli cells.

The next set of experiments was designed to analyze the effect of MET on FSH action on the levels of expression of cell cycle regulators. Figure 6A shows that $10 \mathrm{mM}$ MET decreased FSH-stimulated Ccnd1 and Ccnd2mRNA levels. This figure also shows that FSH produced a slight increase of Ccne 1 and Ccne2 mRNA levels, which was not statistically significant and that a $10 \mathrm{mM}$ dose of MET decreased it. Figure 6B shows that in the presence of $\mathrm{FSH}, 10 \mathrm{mM}$ MET produced a significant increase in $p 21^{\text {Cip } 1}$ mRNA levels while it did not modify $p 27^{\text {Kip } 1}$ mRNA levels. The protein levels of Cyclin D1 and D3 were also evaluated. Similar to the effect on mRNA levels, $10 \mathrm{mM}$ MET decreased FSH-stimulated Cyclin D1 levels, while it did not affect Cyclin D3 levels (Supplementary Fig. 1, see section on supplementary data given at the end of this article).

Finally, considering that in some cancer cells, the anti-proliferative effects of MET are accompanied by a reduction in $c-M y c$ expression, that in Sertoli cells FSH increases $c-M y c$ mRNA levels and that this fact has been related to the regulation of FSH-stimulated Sertoli cell proliferation (Lim \& Hwang 1995), we decided to evaluate the effect of MET on the expression of this transcription factor. In this respect, Fig. 7 shows that MET did not modify Basal or FSH-stimulated c-Myc mRNA levels.
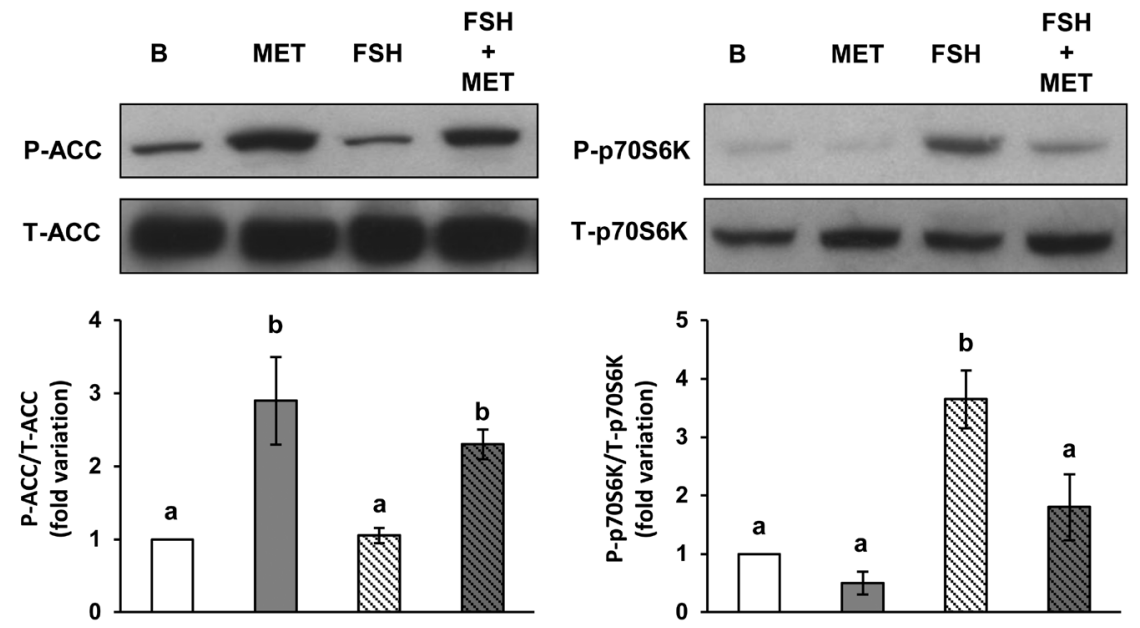

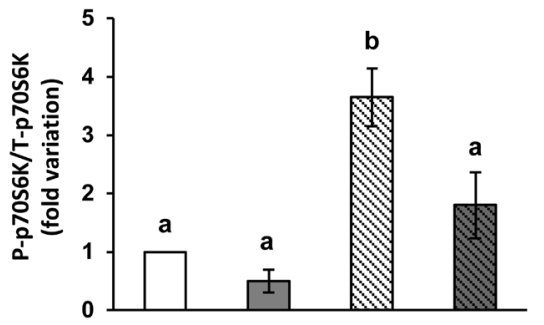

Figure 4 Effect of metformin in the presence of FSH on P-ACC and P-p70S6K levels. Sertoli cell monolayers were maintained under Basal (B) conditions or incubated with $10 \mathrm{mM}$ metformin in the absence or presence of $\mathrm{FSH}$ for $6 \mathrm{~h}$. Western blot analysis was performed utilizing antibodies for P-ACC, T-ACC, P-p70S6K and T-p70S6K. The upper panels show a representative experiment out of three. The lower panels show pooled data of three independent experiments indicating the fold variation in phosphorylation (ratio of P-ACC to T-ACC and of P-p70S6K to T-p70S6K in each sample) relative to Basal. Results are expressed as means \pm S.D. Different letters indicate statistically significant differences $(P<0.05)$. 
Basal

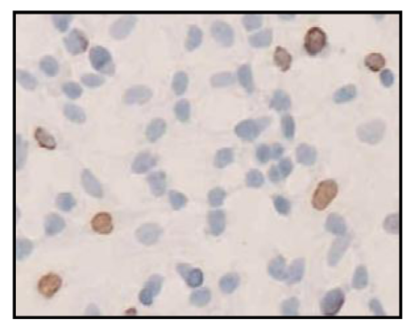

FSH+MET0.5
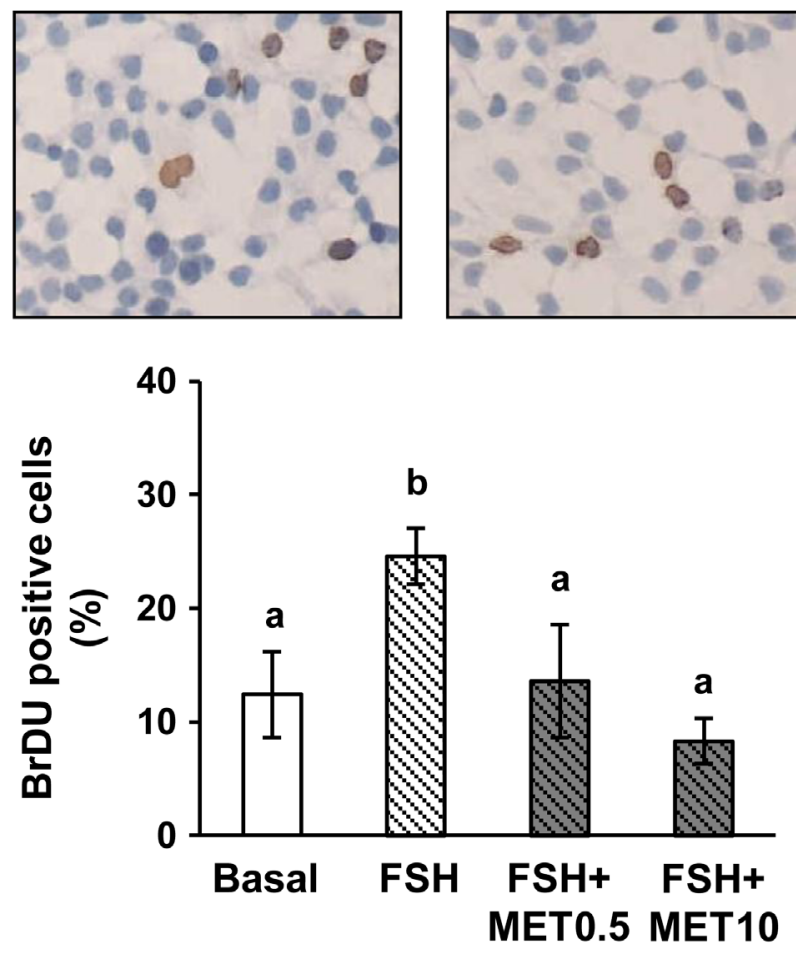

Figure 5 Effect of metformin on FSH-stimulated Sertoli cell proliferation. Sertoli cells monolayers were maintained under Basal (B) conditions or incubated for $24 \mathrm{~h}$ with $\mathrm{FSH}(100 \mathrm{ng} / \mathrm{mL})$ in the absence or presence of metformin $(0.5$ or $10 \mathrm{mM})$. At the end of the culture period, bromodeoxyuridine (BrdU) incorporation was evaluated by immunocytochemistry. Representative images of Sertoli cells showing immunoreactivity for BrdU (brown) were shown. In the graphic, each bar represents \% BrdU-positive cells (2000 cells/ group). Results are presented as means \pm S.D. of four independent experiments. Different letters indicate statistically significant differences $(P<0.05)$.

\section{Discussion}

Sertoli cell proliferation occurs in fetal and postnatal periods up to 15 days of age in the rat. Each Sertoli cell supports a fixed number of germ cells throughout spermatogenesis. Consequently, the final number of Sertoli cells reached during the proliferative periods will determine the number of germ cells that can be maintained and hence define the level of sperm production, an issue with a clear bearing on fertility.
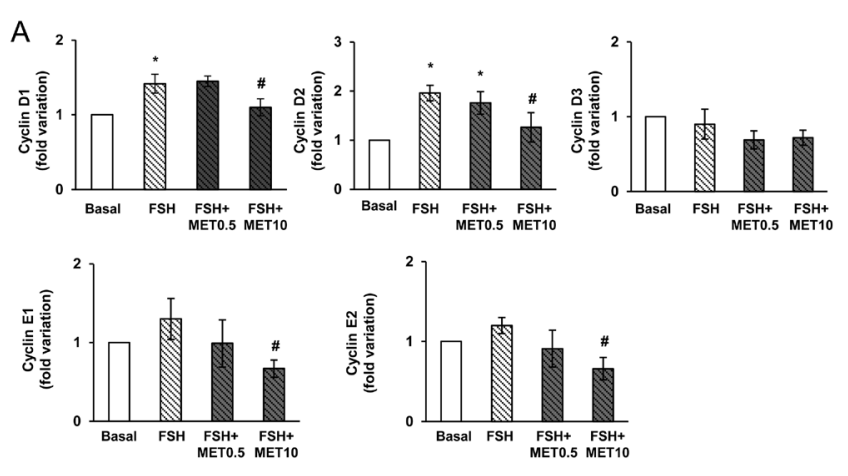

B
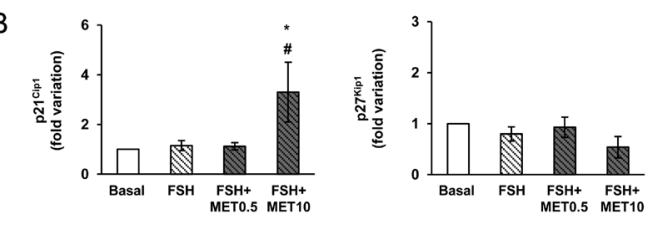

Figure 6 Effect of metformin in the presence of FSH on Ccnd1-d3, Ccne 1 -e2, p2 $1^{\text {Cip } 1}$ and $p 27^{\text {Kip } 1}$ mRNA levels. Sertoli cells monolayers were maintained under Basal conditions or incubated with FSH $(100 \mathrm{ng} / \mathrm{mL})$ in the absence or presence of metformin $(0.5$ or $10 \mathrm{mM})$ for $2 \mathrm{~h}$ (Ccnd1) or $6 \mathrm{~h}$ (Ccnd2-d3; Ccne1-e2) in panel A and for $24 \mathrm{~h}$ $\left(p 21^{\text {Cip1 }}\right.$ and $\left.p 27^{\text {Kip } 1}\right)$ in panel B. Then, total RNA was extracted and RT-qPCR was performed. Graphics show pooled data from four independent experiments performed indicating fold variation in mRNA levels relative to Basal. Results are expressed as means \pm S.D. ( ${ }^{*} P<0.05$ vs Basal; ${ }^{*} P<0.05$ vs FSH).

MET is the most commonly given oral drug for the treatment of $\mathrm{T} 2 \mathrm{D}$, and it has been recently started to be prescribed in pediatric patients (Jones et al. 2002, Brufani et al. 2013, Adeyemo et al. 2015, Smith et al. 2016). The mechanisms through which MET affects cell function have not been fully defined. In this respect, it has been reported that MET acts through AMPKindependent and -dependent mechanisms. In the present study, we observed that MET treatment in Sertoli cells increases P-ACC levels, indirectly showing that activation of AMPK is taking place and that an AMPKdependent mechanism may be altering cell function. Additionally, it was observed that MET decreases the activity of the p70S6K pathway. These results are in agreement with observations made in several cell lines showing that MET activates AMPK and inhibits p70S6K pathway (Zakikhani et al. 2006, Qu et al. 2012, White-Al Habeeb et al. 2016). The notion that activation of AMPK and decreased activity of p70S6K pathways are related events in Sertoli cells is supported by previous studies demonstrating that AMPK activation by the pharmacological activator A-769662 promotes an inhibition of p70S6K signaling in this cell type (Riera et al. 2012).

In the last years, the effect of MET on the regulation of cell proliferation has captured much attention. Specifically, the potential antitumoral effect of this drug has been evaluated. It has been demonstrated that MET causes G1/S phase cell cycle arrest in several 


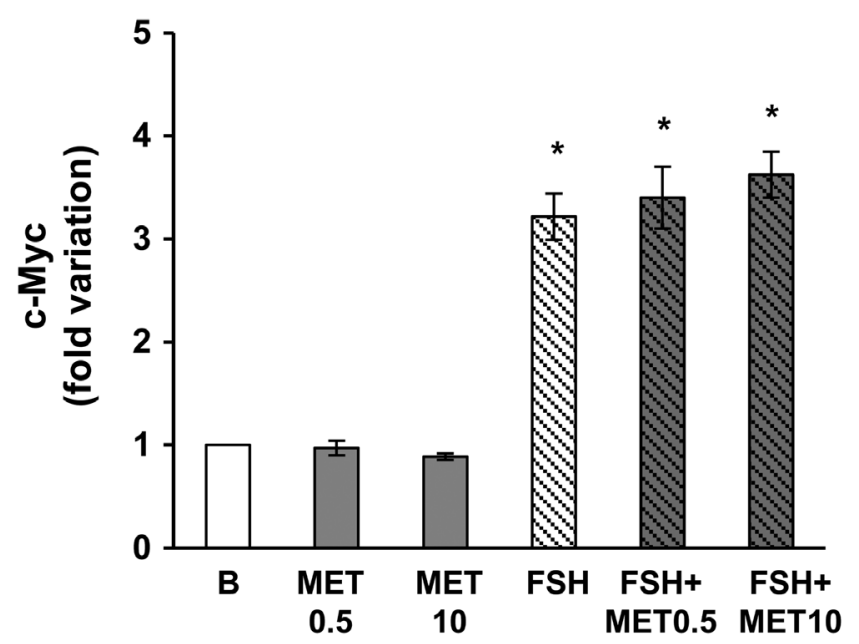

Figure 7 Effect of metformin on c-Myc mRNA levels. Sertoli cells monolayers were incubated under Basal conditions or stimulated for $2 \mathrm{~h}$ with $\mathrm{FSH}(100 \mathrm{ng} / \mathrm{mL})$ in the absence or presence of metformin ( 0.5 or $10 \mathrm{mM})$. Then, total RNA was extracted and RT-qPCR was performed. Graphics show pooled data from four independent experiments performed indicating fold variation in mRNA levels relative to Basal. Results are expressed as means \pm S.D. $\left({ }^{*} P<0.05\right.$ vs Basal).

cancer cells such as human head and neck squamous cell carcinoma (HNSCC) cells, esophageal squamous cell carcinoma (ESCC) cells and breast cancer cells among others (Zhuang \& Miskimins 2008, Sikka et al. 2012, Cai et al. 2015 ). The results presented herein show that MET decreases BrdU incorporation into DNA and total cell number without modifying cell viability demonstrating that the drug induces an inhibition of rat Sertoli cell proliferation. Our results are in agreement with those presented by Tartarin et al. (2012) who observed that in vivo administration of MET to pregnant mice showed a reduced number of Sertoli cells in newborn pups. It has also been recently observed that MET decreases the proliferation of Sertoli cells obtained from peripubertal chickens (Faure et al. 2016). Altogether, these results suggest that MET can affect Sertoli cell proliferation at different stages of development and consequently can modify final Sertoli cell number reached in adulthood, which may eventually compromise fertility.

The present study also attempted to uncover the molecular mechanisms that may be involved in MET effects on Sertoli cell proliferation. Cyclins and cell cycle inhibitors tightly control cell cycle progression and the effect of MET on the regulation of their expression has been analyzed in some cell lines. Previous studies have shown a downregulation of cyclin D1 expression in response to MET in MCF7 breast cancer cells and in prostate cancer cell lines (Ben Sahra et al. 2008, Zhuang \& Miskimins 2008). As for cell cycle inhibitors, it has been demonstrated that MET increases p2 $1^{\text {Cip } 1}$ and p2 $7^{\text {Kip1 }}$ protein levels in ESCC cells and in hepatocellular carcinoma (HCC) cell lines (Cai et al. 2013, 2015). Our results show that MET decreases Ccnd1 and Ccne1 mRNA levels in rat Sertoli cells. In addition, results show that MET promotes a marked increase in the expression of $p 21^{\text {Cip } 1}$. Altogether, these data strongly suggest that MET may reduce Sertoli cell proliferation through the regulation of the expression of cyclins and/or cell cycle inhibitors.

Despite the fact that it has been observed that MET can inhibit Sertoli cell proliferation in other experimental models (Tartarin et al. 2012, Faure et al. 2016), none of these studies have analyzed the effect of this drug on the hormonal regulation of cell proliferation. Even though a role for several hormones has been assigned in Sertoli cell proliferation, it is widely accepted that FSH is the major Sertoli cell mitogen (Griswold et al. 1977, Archambeault \& Yao 2010, Lucas et al. 2014). Several signal transduction pathways may participate in FSH stimulation of Sertoli cell proliferation (Orth 1984, Crépieux et al. 2001). Particularly, it has been shown that FSH activates mTORC1/p70S6K pathway in order to increase Sertoli cell proliferation (Riera et al. 2012). In the present study, we show that even in the presence of FSH, MET can activate AMPK, and it diminishes FSH-stimulated P-p70S6K levels, indicating that MET is able to inhibit at least one of the signaling pathways activated by FSH to promote proliferation of Sertoli cells.

Considering that MET can counteract signaling pathways activated by $\mathrm{FSH}$, possible effects of this drug on FSH-stimulated Sertoli cell proliferation may be expected. In fact, results presented herein show that MET inhibits FSH-stimulated Sertoli cell proliferation. The latter decrease in FSH-stimulated Sertoli cell proliferation may be accounted for by, at least in part, a decrease in FSHstimulated Ccnd 1 and $C$ cnd 2 expression and a marked increase in the expression of the cell cycle inhibitor p2 ${ }^{\text {Cip } 1}$. Upregulation of $p 21^{\text {Cip } 1}$ expression by AMPK activation has been previously linked to the inhibition of proliferation in FSH-stimulated Sertoli cells (Riera et al. 2012). It is noteworthy that testosterone, retinoic acid and triiodothyronine - hormones that promote physiological cessation of Sertoli cell proliferation - also increase p21 ${ }^{\text {Cip } 1}$ expression (Buzzard et al. 2003).

There is a vast amount of evidence pointing out the important role that c-Myc has on cell proliferation. As mentioned before, FSH increases c-Myc mRNA levels in eight-day-old rat Sertoli cells and that regulation of c-Myc expression has been suggested to be involved in the proliferative effect of FSH (Lim \& Hwang 1995, Riera et al. 2012). Moreover, studies performed utilizing different cancer cell lines have shown that MET exerts anti-proliferative actions, at least in part, by decreasing c-Myc expression (Mogavero et al. 2017, Zhang et al. 2017). The above-mentioned observations led us to evaluate a possible effect of MET on the regulation of c-Myc mRNA levels. Our results showing that MET does 
not modify Basal- or FSH-stimulated c-Myc mRNA levels indicate that the decrease of Sertoli cell proliferation produced by MET may not be related to the expression of this transcription factor.

One of the major obstacles for extrapolating the findings of MET action in cultured cells to the human being as a whole is the difference between MET concentrations used in in vitro studies and plasma levels of this drug reached in treated patients which are in the micromolar range. In our study, as in most of the investigations that analyze the effects of MET on cell proliferation, MET concentrations of $0.5-10 \mathrm{mM}$ were necessary to inhibit Sertoli cell proliferation. A recent publication offers insights into what otherwise seems to be a non-physiological effect of MET. Gui et al. (2016) analyzed the anti-proliferative effect of MET in different culture media and showed that the presence of pyruvate in the culture medium diminishes the sensitivity to MET by approximately two orders of magnitude. The mechanism involves pyruvate availability as this ketoacid can act as an electron acceptor to regenerate NAD+ with the result of a change in the cell dependency to respiratory complex I activity (Gui et al. 2016). Considering that our culture medium contains $1 \mathrm{mM}$ pyruvate, this may well explain why only elevated doses of MET inhibit Sertoli cell proliferation.

Sertoli cells proliferate during distinct periods in life, which include fetal, neonatal life and beginning of puberty in all species. In the rat, the neonatal and pubertal period are superimposed (Sharpe et al. 2003). Once they passed these proliferative periods, Sertoli cells remain numerically stable throughout life, and it is widely accepted that this number determines sperm production. Altogether, our findings suggest that MET can counteract, at least in part, the effect of FSH on postnatal rat Sertoli cell proliferation. Bearing in mind that MET is now being used for the therapy of obesity and T2D in children starting at the age of 6 years (Brufani et al. 2013, Smith et al. 2016), which include ages where Sertoli cells proliferate, attention should be paid to possible alterations in the final number of Sertoli cells in adulthood. A longitudinal study evaluating fertility in these patients would be helpful to gain full confidence on MET treatment in children.

\section{Supplementary data}

This is linked to the online version of the paper at https://doi.org/10.1530/REP-18-0233.

\section{Declaration of interest}

The authors declare that there is no conflict of interest that could be perceived as prejudicing the impartiality of the research reported.

\section{Funding}

This work was supported by the Agencia Nacional de Promoción Científica y Tecnológica (PICT 2014/945; PICT2015/228) and the Consejo Nacional de Investigaciones Científicas y Técnicas (CONICET) (PIP 2015/127). M N Galardo, S B Meroni and M F Riera are established investigators of CONICET. G M Rindone and M Regueira are recipients of CONICET fellowships; A Gorga is a recipient of ANPCyT fellowship.

\section{Acknowledgements}

The authors express their gratitude to Dr Abramovich D for providing the Cyclin D1 antibody. The technical help of Mercedes Astarloa is gratefully acknowledged.

\section{References}

Adeyemo MA, McDuffie JR, Kozlosky M, Krakoff J, Calis KA, Brady SM \& Yanovski JA 2015 Effects of metformin on energy intake and satiety in obese children. Diabetes Obesity and Metabolism 17 363-370. (https:// doi.org/10.1111/dom.12426)

Archambeault DR \& Yao HH 2010 Activin A, a product of fetal Leydig cells, is a unique paracrine regulator of Sertoli cell proliferation and fetal testis cord expansion. PNAS 107 10526-10531. (https://doi.org/10.1073/ pnas.1000318107)

Ben Sahra I, Laurent K, Loubat A, Giorgetti-Peraldi S, Colosetti P, Auberger P, Tanti JF, Le Marchand-Brustel Y \& Bost F 2008 The antidiabetic drug metformin exerts an antitumoral effect in vitro and in vivo through a decrease of cyclin D1 level. Oncogene 27 3576-3586. (https://doi.org/10.1038/sj.onc.1211024)

Brufani C, Crinò A, Fintini D, Patera PI, Cappa M \& Manco M 2013 Systematic review of metformin use in obese nondiabetic children and adolescents. Hormone Research in Paediatrics 80 78-85. (https://doi. org/10.1159/000353760)

Buzzard JJ, Wreford NG \& Morrison JR 2003 Thyroid hormone, retinoic acid, and testosterone suppress proliferation and induce markers of differentiation in cultured rat Sertoli cells. Endocrinology $\mathbf{1 4 4}$ 3722-3731. (https://doi.org/10.1210/en.2003-0379)

Cai X, Hu X, Cai B, Wang Q, Li Y, Tan X, Hu H, Chen X, Huang J, Cheng J et al. 2013 Metformin suppresses hepatocellular carcinoma cell growth through induction of cell cycle G1/G0 phase arrest and p21CIP and p27KIP expression and downregulation of cyclin D1 in vitro and in vivo. Oncology Reports 30 2449-2457. (https://doi.org/10.3892/ or.2013.2718)

Cai X, Hu X, Tan X, Cheng W, Wang Q, Chen X, Guan Y, Chen C \& Jing X 2015 Metformin induced AMPK activation, G0/G1 phase cell cycle arrest and the inhibition of growth of esophageal squamous cell carcinomas in vitro and in vivo. Public Library of Science 10 e0133349. (https://doi. org/10.1371/journal.pone.0133349)

Crépieux P, Marion S, Martinat N, Fafeur V, Vern YL, Kerboeuf D, Guillou F \& Reiter E 2001 The ERK-dependent signalling is stage-specifically modulated by FSH, during primary Sertoli cell maturation. Oncogene 20 4696-4709. (https://doi.org/10.1038/sj.onc.1204632)

Faure M, Guibert E, Alves S, Pain B, Ramé C, Dupont J, Brillard JP \& Froment P 2016 The insulin sensitiser metformin regulates chicken Sertoli and germ cell populations. Reproduction 151 527-538. (https:// doi.org/10.1530/REP-15-0565)

Gowans GJ \& Hardie DG 2014 AMPK: a cellular energy sensor primarily regulated by AMP. Biochemical Society Transactions 42 71-75. (https:// doi.org/10.1042/BST20130244)

Griswold MD, Solari A, Tung PS \& Fritz IB 1977 Stimulation by folliclestimulating hormone of DNA synthesis and of mitosis in cultured Sertoli cells prepared from testes of immature rats. Molecular and Cellular Endocrinology 7 151-165. (https://doi.org/10.1016/03037207(77)90064-8)

Gui DY, Sullivan LB, Luengo A, Hosios AM, Bush LN, Gitego N, Davidson SM, Freinkman E, Thomas CJ \& Vander Heiden MG 2016 
Environment dictates dependence on mitochondrial complex I for $\mathrm{NAD}+$ and aspartate production and determines cancer cell sensitivity to metformin. Cell Metabolism 24 716-727. (https://doi.org/10.1016/j. cmet.2016.09.006)

Hardie DG, Hawley SA \& Scott JW 2006 AMP-activated protein kinasedevelopment of the energy sensor concept. Journal of Physiology $\mathbf{5 7 4}$ 7-15. (https://doi.org/10.1113/jphysiol.2006.108944)

Isakovic A, Harhaji L, Stevanovic D, Markovic Z, Sumarac-Dumanovic M Starcevic V, Micic D \& Trajkovic V 2007 Dual antiglioma action of metformin: cell cycle arrest and mitochondria-dependent apoptosis. Cellular and Molecular Life Sciences 64 1290-1302 (https://doi. org/10.1007/s00018-007-7080-4)

Jones KL, Arslanian S, Peterokova VA, Park JS \& Tomlinson MJ 2002 Effect of metformin in pediatric patients with type 2 diabetes: a randomized controlled trial. Diabetes Care 25 89-94. (https://doi.org/10.2337/ diacare.25.1.89)

Lim K \& Hwang BD 1995 Follicle-stimulating hormone transiently induces expression of protooncogene c-myc in primary Sertoli cell cultures of early pubertal and prepubertal rat. Molecular and Cellular Endocrinology 111 51-56. (https://doi.org/10.1016/0303-7207(95)03543-G)

Lucas TF, Nascimento AR, Pisolato R, Pimenta MT, Lazari MF \& Porto CS 2014 Receptors and signaling pathways involved in proliferation and differentiation of Sertoli cells. Spermatogenesis 20 e28138. (https://doi. org/10.4161/spmg.28138)

Meroni SB, Riera MF, Pellizzari EH \& Cigorraga SB 2002 Regulation of rat Sertoli cell function by FSH: possible role of phosphatidylinositol 3-kinase/protein kinase B pathway. Journal of Endocrinology 174 195-204. (https://doi.org/10.1677/joe.0.1740195)

Mogavero A, Maiorana MV, Zanutto S, Varinelli L, Bozzi F, Belfiore A, Volpi CC, Gloghini A, Pierotti MA \& Gariboldi M 2017 Metformin transiently inhibits colorectal cancer cell proliferation as a result of either AMPK activation or increased ROS production. Science Reports 7 15992. (https://doi.org/10.1038/s41598-017-16149-z)

Orth JM 1984 The role of follicle-stimulating hormone in controlling Sertoli cell proliferation in testes of fetal rats. Endocrinology 115 1248-1255. (https://doi.org/10.1210/endo-115-4-1248)

Qu Z, Zhang Y, Liao M, Chen Y, Zhao J \& Pan Y 2012 In vitro and in vivo antitumoral action of metformin on hepatocellular carcinoma. Hepatology Research 42 922-933. (https://doi.org/10.1111/j.1872034X.2012.01007.x)

Rattan R, Giri S, Hartmann LC \& Shridhar V 2011 Metformin attenuates ovarian cancer cell growth in an AMP-kinase dispensable manner. Journal of Cellular and Molecular Medicine 15 166-178. (https://doi. org/10.1111/j.1582-4934.2009.00954.x)

Rey RA, Campo SM, Ropelato MG \& Bergadá I 2016 Hormonal changes in childhood and puberty. In Puberty, pp 23-37. Eds P Kumanov \& A Agarwal. Springer International Publishing, Switzerland (https://doi org/10.1007/978-3-319-32122-6_3).
Riera MF, Regueira M, Galardo MN, Pellizzari EH, Meroni SB \& Cigorraga SB 2012 Signal transduction pathways in FSH regulation of rat Sertoli cell proliferation. American Journal of Physiology: Endocrinology and Metabolism 302 E914-E923. (https://doi. org/10.1152/ajpendo.00477.2011)

Sharpe RM, McKinnell C, Kivlin C \& Fisher JS 2003 Proliferation and functional maturation of Sertoli cells, and their relevance to disorders of testis function in adulthood. Reproduction 125 769-784. (https://doi. org/10.1530/rep.0.1250769)

Sikka A, Kaur M, Agarwal C, Deep G \& Agarwal R 2012 Metformin suppresses growth of human head and neck squamous cell carcinoma via global inhibition of protein translation. Cell Cycle 11 1374-1382. (https://doi.org/10.4161/cc.19798)

Smith JD, Mills E \& Carlisle SE 2016 Treatment of pediatric type 2 diabetes. Annals of Pharmacotherapy 50 768-777. (https://doi. org/10.1177/1060028016655179)

Tartarin P, Moison D, Guibert E, Dupont J, Habert R, Rouiller-Fabre V, Frydman N, Pozzi S, Frydman R, Lecureuil C et al. 2012 Metformin exposure affects human and mouse fetal testicular cells. Human Reproduction 27 3304-3314. (https://doi.org/10.1093/humrep/des264)

White-Al Habeeb NM, Garcia J, Fleshner N \& Bapat B 2016 Metformin elicits antitumor effects and downregulates the histone methyltransferase multiple myeloma SET domain (MMSET) in prostate cancer cells. Prostate 76 1507-1518. (https://doi.org/10.1002/pros.23235)

Zakikhani M, Dowling R, Fantus IG, Sonenberg N \& Pollak M 2006 Metformin is an AMP kinase-dependent growth inhibitor for breast cancer cells. Cancer Research 66 10269-10273. (https://doi.org/10.1158/00085472.CAN-06-1500)

Zakikhani M, Dowling RJ, Sonenberg N \& Pollak MN 2008 The effects of adiponectin and metformin on prostate and colon neoplasia involve activation of AMP-activated protein kinase. Cancer Prevention Research 1 369-375. (https://doi.org/10.1158/1940-6207.CAPR-08-0081)

Zhang J, Xu H, Zhou X, Li Y, Liu T, Yin X \& Zhang B 2017 Role of metformin in inhibiting estrogen-induced proliferation and regulating $E R \alpha$ and $E R \beta$ expression in human endometrial cancer cells. Oncology Letters $\mathbf{1 4}$ 4949-4956. (https://doi.org/10.3892/ol.2017.6877)

Zhuang Y \& Miskimins WK 2008 Cell cycle arrest in Metformin treated breast cancer cells involves activation of AMPK, downregulation of cyclin D1, and requires p27Kip1 or p21Cip1. Journal of Molecular Signalling 3 18. (https://doi.org/10.1186/1750-2187-3-18)

Received 3 October 2017

First decision 8 November 2017

Revised manuscript received 8 May 2018

Accepted 21 May 2018 